\title{
OBITUARY
}

SIR PHILIP PANTON

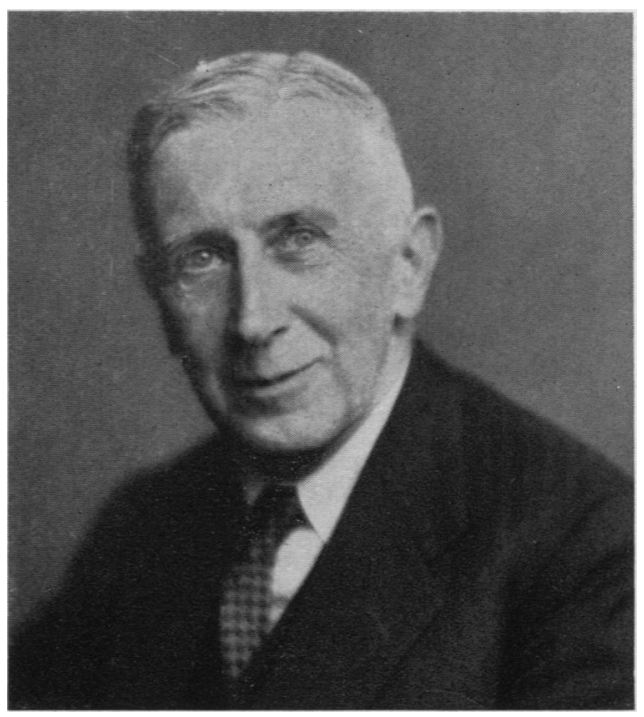

Walter Stoneman, London.

$\mathbf{P}$

HILIP NOEL PANTON was born in 1877 at Wareham, in Dorset, the son of James Panton and grandson of Frith the Victorian artist. He was educated at Harrow and was the first boy in this school to study science, a fact which he always recollected with interest. At school with him were two great national figures-Winston Churchill and L. S. Amery-and it is interesting to note that a housemaster at that time told Panton that L. S. Amery was far the cleverer boy and would be a future Prime Minister of England.

After leaving Harrow he proceeded to Trinity College, Cambridge, and having decided to study medicine he did his clinical work at St. Thomas's Hospital. He qualified with the Cambridge M.B. degree in 1903 and held house appointments at Addenbrooke's Hospital. He was responsible for initiating the use of autoclaved dressings there, using improvised metal containers. It was at this time that he became interested in cross-infection in hospital wards, a study which he continued when he returned to St. Thomas's as Louis Jenner research scholar under Dudgeon, whom he always described as the first clinical pathologist in London. The subject of crossinfection formed the basis for his Cambridge thesis for the M.D. degree, but a regrettable dispute with Clifford Allbutt led to his refusing to proceed to the degree although the thesis had been accepted.

After being a Gilson research scholar of the Society of Apothecaries Panton was appointed assistant director of the clinical laboratories at St. Thomas's Hospital, a post he resigned on being appointed in 1908 as chemical pathologist to the London 
Hospital. He soon had the name of the post altered to that of "clinical" pathologist, and it was in this position that he remained until he resigned from the London Hospital staff in 1946.

In the years before 1914 he rapidly established himself as a reliable consultant and built up a large private practice in pathology. At this time he wrote the first edition of his book Clinical Pathology.

During the first world war he carried out research on T.N.T. poisoning, and in 1918 took a commission in the R.A.M.C. but only held it for a very short time.

It was in the two decades of the inter-war years that he did most for the laboratory services of the London Hospital. He appreciated that to produce their best work research workers must be freed of all routine duties but nevertheless should have full access to the material passing through the routine departments. He enlisted the financial aid of the Rev. M. S. Courtauld, and the Freedom Research Fellowships were established; Howard Florey and S. P. Bedson were the first Fellows.

Panton himself was not a great research worker, although he stimulated others to take up research and provided them with facilities to work. He wrote papers on pernicious anaemia, gastric acidity, lymphatic leukaemia, staphylococcal toxins, and in 1939 he published a review of all the known cancer tests. He was a great reader of medical literature and each day spent at least two hours in reading. This enabled him to advise with accuracy on the diagnosis and management of obscure cases, and until he finally retired he was well abreast of the new techniques.

His undergraduate teaching was not very successful, mainly because his conversational tone was difficult to follow except for those in the front rows of his audience, but he was a first-class director of the studies of postgraduate students and proved to be an excellent examiner; he particularly enjoyed examining at Oxford for the M.B. degree.

In 1938 he began to prepare for the possibility of war, and with W. W. C. Topley compiled a record of all pathologists and medical laboratory technicians. This index subsequently proved to be of great value, especially in fitting suitable people into posts in the Services. He was a sector pathologist in the E.M.S. in 1939, but was asked to take up the new post of consultant in pathology at the Ministry of Health in 1940.

For the next seven years he devoted himself to two objects; first to direct a blood transfusion service for the whole country, and secondly to establish a well-organized hospital laboratory service not only for the new emergency hospitals but also one capable of balanced expansion after the war. The development of the transfusion service was of the greatest urgency, and Panton devoted much time to seeing that the regional blood transfusion directors were the best available and that they were given a very free hand. He was also responsible for seeing that the Leeds centre was built up to act as an adjunct to the Army Transfusion Service, and the success of this co-operation gave him great pleasure.

Throughout the war he travelled to every important hospital laboratory in England and Wales, helping the pathologists, arranging for meetings of regional pathologists, and smoothing away local difficulties standing in the path of expansion. He was a good judge of character, and, although many of the young pathologists who had to take charge of laboratories were inevitably woefully lacking in experience, hospital 
staffs who were reluctant to welcome a visiting pathologist often complained later if expansion of their laboratory service did not seem to be rapid enough.

In committees at the Ministry he was at his best-tactful, clear-sighted, and so patently honest that he won over Civil Servants to his point of view with the minimum of effort. He never lost sight of the ultimate objective, a first-class hospital laboratory service with pathologists holding equal status with their clinical colleagues. He appreciated the difference between public health bacteriology and hospital bacteriology, and cordially co-operated with Professor G. S. Wilson when the Emergency Public Health laboratory service was being built up. As a member of the Services Committee he advised on the calling up of pathologists for the armed Forces, and his advice was rarely set aside.

Pathologists learned to come to him for advice; he was friendly, hospitable, informed, and always helpful. He felt that a whole-time salaried service was inevitable in hospital pathology, and in spite of the years he had spent in consultant practice he doubted if private practice in pathology would continue.

In 1946 he was rewarded for his war services with a knighthood which he accepted partly, and characteristically, because he said it would help to impress lay committees when he was trying to persuade them to set up adequate laboratory services in their hospitals. In 1946 he lectured in Prague on behalf of the British Council.

After 1948 his work at the Ministry decreased and he was able to spend more time in his delightful garden, his water-garden being his particular joy. Many pathologists will remember with pleasure his informal hospitality at Bourne End. After a very short retirement he had his first coronary thrombosis, but recovered well only to suffer another attack later. He died on December 27, 1950.

It should not be forgotten that the enhanced status of hospital pathologists, and the framework of an adequate laboratory service for the whole country, are largely due to Panton's tireless efforts. Others might have done what he did but none would have done it so well.-H. B. M.

\section{STEPHEN ROODHOUSE GLOYNE}

Everyone who had the privilege of knowing and working with Stephen Gloyne was impressed by the essential goodness of his character. It was for this reason that those who had his friendship would repeatedly turn to him for counsel and advice on personal as well as professional matters. His instinctive sympathy and appreciation of problems put to him enabled him to give a judgment that was invariably helpful and stimulating.

Professionally Gloyne was in a unique position for many years as the doyen of chest pathology. After a thorough preliminary training in all branches of pathology he came to the London Chest Hospital, which was his headquarters until he retired. With this position he was content, though in his earlier days he had opportunities for taking up posts which would have led to higher academic rewards. He made many contributions on the morbid anatomy of lung disease, notably silicosis and tuberculosis, and correlated these with the clinical and social aspects of disease. Possibly his most popular lectures and writings were connected with the pathenogenesis of cuberculosis, and his presidency of the Tuberculosis Association was notable for the broad philosophical outlook of the discussions. 